WAGERING THE LAND 


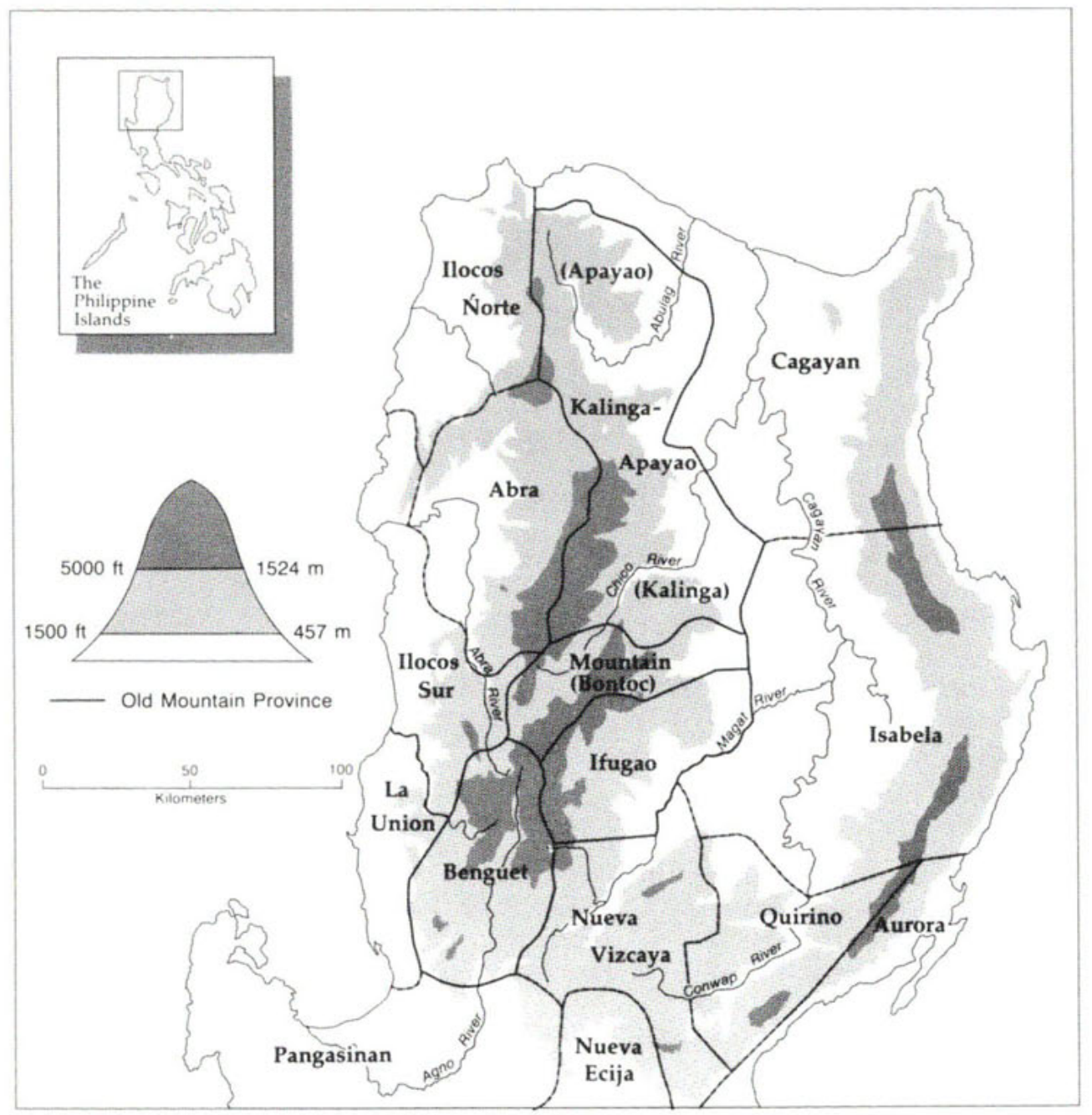

Map 1. Northern Luzon: Topography and Provincial Boundaries. 


\title{
WAGERING THE LAND
}

\author{
RITUAL, CAPITAL, \\ AND ENVIRONMENTAL \\ DEGRADATION IN THE \\ CORDILLERA OF \\ NORTHERN LUZON, \\ $1900-1986$
}

Martin W. Lewis

UNIVERSITY OF CALIFORNIA PRESS

Berkeley · Los Angeles · Oxford 
The author thanks the Association of American Geographers for permission to reprint much of chapter 4 and maps 1, 2, 3, 4, 6, 7,8, and 9 from Annals of the Association of American Geographers (C) 1989.

University of California Press

Berkeley and Los Angeles, California

University of California Press

Oxford, England

Copyright (C) 1992 by The Regents of the University of California

\section{Library of Congress Cataloging-in-Publication Data}

\section{Lewis, Martin W.}

Wagering the land : ritual, capital, and environmental degradation in the Cordillera of northern Luzon, 1900-1986 / Martin W. Lewis.

p. $\mathrm{cm}$.

Includes bibliographical references (p. ) and index. ISBN 0-520-07272-3 (cloth : alk. paper)

1. Man-Influence on nature-Philippines-Buguias. 2. Agricultural ecology-Philippines-Buguias. 3. Tropical vegetable industry-Philippines-Buguias. 4. Agriculture-Economic aspects-Philippines-Buguias.

5. Agriculture-Social aspects-Philippines-Buguias.

6. Rites and ceremonies-Philippines-Buguias.

7. Buguias (Philippines)-Politics and government. 8. Buguias (Philippines)-Religous life and customs. I. Title. GF852.P6L48 1992 333. 6 $^{\prime} 09599^{\prime} 1$ - de2o

Printed in the United States of America

123456789

The paper used in this publication meets the minimum requirements of American National Standard for Information Sciences-Permanence of Paper for Printed Library Materials, ANSI Z39.48-1984 @ 